Ege Tıp Dergisi / Ege Journal of Medicine 2018;57(2):116-118

\title{
Elektrik çarpması sonucu meydana gelen yaralanmaların adli-tıbbi değerlendirmesi
}

\author{
Forensic medical evaluation of electric shock injury \\ Faruk Aydın ${ }^{1} \quad$ Mehmet Sunay Yavuz ${ }^{1} \quad$ Ufuk Akın ${ }^{1} \quad$ İlknur Kahraman ${ }^{2}$ \\ ${ }^{1}$ Manisa Celal Bayar Üniversitesi Tıp Fakültesi, Adli Tıp Anabilim Dalı, Manisa, Türkiye \\ ${ }^{2}$ Adli Tıp Kurumu, Kilis Adli Tıp Şube Müdürlüğü, Kilis, Türkiye
}

\section{Öz}

Elektrik akımı maruziyeti sonucu ölümcül kazaların sayısı hala yüksektir. Elektrik çarpmaları en sık kaza sonucu olduğu görülmektedir. TCK'da tanımlanan "Yaralama Suçlarının Adli Tıp Açısından Değerlendirilmesi” kılavuzunda elektrik yaralanmaları hususunda; giriş ve/veya çıkış lezyonu bulunması, vücuttan elektrik akımının geçtiğini gösteren klinik bulguların varlığı veya sağlık personeli tarafından kardiyopulmoner resüsitasyon uygulandığı durumlar yaşamsal tehlike olarak değerlendirilmiştir. Çalışmamızda elektrik çarpması sonucu saptanan bulgular eşliğinde oluşan lezyonların medikolegal açıdan tartışılması amaçlanmıştır. On yaşında erkek olgunun tıbbi belgelerinde elektrik çarpması giriş lezyonu tespit edildiği halde tetkiklerinde herhangi bir patoloji saptanmadığı bildirilmiştir. Bu olgunun yaralanmasının değerlendirmesi hususunda kılavuz dikkate alındığında yaşamsal tehlikeye neden olduğu belirtilmesi gerekirken, bizim değerlendirmemiz; vücudu kat etmeyen, elektrik akımı teması sonucu termal yanık ile karakterize lezyon oluşumuna neden olan yaralanmanın basit tıbbi müdahale ile giderilebilecek nitelikte olduğu şeklindedir. Elektrik çarpması sonucu meydana gelen yaralanmaların adli-tıbbi değerlendirmesi için daha objektif, sınırları daha geniş ve belirgin ölçütlerin kılavuzda yer alması gerektiği kanaatindeyiz.

Anahtar Sözcükler: Elektrik çarpması, adli tıp, adli-tıbbi değerlendirme.

\begin{abstract}
The number of fatal accidents due to electrical current exposure are still high. Electrical shocks are mostly seen as an accidental event. For electrical injuries in the guideline; presence of clinical signs indicating the presence of an entry or exit lesion, electrical transmission of the body, or cardiopulmonary resuscitation performed by a health personnel were considered as a life threatening condition. In our study, we aimed to discuss the lesions and other findings that occured as a result of electrical shock in medicolegal context. A 10-year-old male patient was reported to have no pathology in his examinations, even though an electrical lesion was detected. If the guideline is taken into account in the assessment of this patient's injury, it must be life threatening hazard. We evaluated that the injury led to the formation of a lesion that was characterized with the thermal burn due to a contact with the electric current and that this injury could be eliminated by simple medical intervention. We believe that more objective and clearer measures with wider boundaries should be included in the guideline for the purpose of judicial-medical evaluation of injuries resulting from electric shocks.
\end{abstract}

Keywords: Electric shock, forensic medicine, forensic medical evaluation.

\section{Giriş}

Teknolojik ve endüstriyel gelişmelere paralel olarak elektrik enerjisi günlük yaşantımızda yaygın ve artış gösteren kullanım alanına sahiptir (1-4). Bu yaygın kullanımdaki artışla orantılı olmasa da, elektrik akımı maruziyeti sonucu deri lezyonları, iç organ hasarları gibi yaralanmaların ve ölümcül kazaların sayısı yüksektir (1-3).

\footnotetext{
Yazışma Adresi: Mehmet Sunay Yavuz

Manisa Celal Bayar Üniversitesi Tıp Fakültesi, Adli Tıp Anabilim Dalı, Manisa, Türkiye
}

Makalenin Geliş Tarihi: 08.08.2017

Kabul Tarihi: 25.08.2017
Elektrik çarpması, elektrik kaynağı ile temas sonucu akımın kişinin vücudunu geçerek yaralaması veya ölümü olarak tanımlanmaktadır (1). Yüksek voltajlı elektrik akımı, aritmi veya solunum kaslarında paraliziye yol açarak ani ölüme neden olabileceği gibi, ölümle sonuçlanmayan olgularda ağır yanıklar ve çoklu sistem etkilenimi sonucu morbidite ve uzun dönemde sekellere yol açar (1-6). Elektrik akımının insan vücudu üzerindeki etkisi; akımın temas süresi ve yoğunluğu, temas ettiği dokuların direnci ve vücutta izlediği yol gibi birçok değişkene bağlıdır (1-5). Elektrik çarpmalarında orijin en sık kaza nedenli olmakla birlikte literatürde intihar ve cinayet olguları da bildirilmektedir $(1,2)$. 
Ölümle sonuçlanmayan elektrik çarpmasına maruz kalan olgularda meydana gelen zarar, cezai ve hukuki yönlerden değerlendirmeye esas olacak şekilde ortaya koyulmalıdır. Cezai yönden travma sonucu meydana gelen yaralanmanın ağırlık derecesi, yaralanmaya neden olan şahsa/kuruma verilecek cezayı belirleyen önemli unsurlardan biridir. Türk Ceza Kanunu'nun ilgili maddelerinde yaralama fiilinin kişi üzerindeki etkisinin yaşamını tehlikeye sokan bir duruma neden olması halinde, cezada artırım öngörülür (7).

TCK'da Tanımlanan Yaralama Suçlarının Adli Tıp Açısından Değerlendirilmesi kılavuzunda elektrik yaralanmaları iki yerde karşımıza çıkmaktadır. İlk olarak giriş ve/veya çıkış lezyonu bulunması veya vücuttan elektrik akımının geçtiğini gösteren klinik bulguların varlığı durumunda elektrik çarpması yaşamı tehlikeye sokan bir yaralanma olarak değerlendirilir. İkinci olarak vücuttan elektrik akımının geçtiğine dair pozitif bulguların mevcut olduğu ve/veya sağlık personeli tarafından kardiyopulmoner resüsitasyon uygulandığı durumlar yine yaşamsal tehlike sınıfına sokulur (8).

Çalışmamızda sunduğumuz olgumuzda saptanan bulgular ve yapılan değerlendirmede, kılavuzda yaşamsal tehlikeye giren yaralanma olmasına rağmen gerekli gerekçelerle rapor sonucumuz yaralanmanın basit tıbbi müdahale ile giderilebileceği şeklinde olmuştur. Meydana gelen yaralanma nedeniyle kesin rapor düzenlenmesi amacıyla Anabilim Dalımıza gönderilen olgu, yasal vasisinden tıbbi verilerinin yayınlanabileceğine ilişkin yazılı onam belgesi alınarak, elektrik çarpması sonucu meydana gelen yaralanmalar kılavuzdaki ölçütler eşliğinde medikolegal açıdan tartışıldı.

\section{Olgu Sunumu}

10 yaşında erkek olgu, hakkında adli rapor düzenlenmesi istemiyle babasıyla birlikte Anabilim Dalımıza müracaat etmiştir. Alınan anamnezde; tatil için gittikleri otel odasında sağ el 3. parmağını abajurun duy kısmına dokundurmak suretiyle elektrik akımına maruz kaldığı, annesinin yardımıyla akımdan ayrıldığı, bilinç kaybı yaşamadığı, olay yerine çağrılan ambulansla hastaneye götürüldüğü öğrenilmiştir. İncelenen tıbbi belgelerde; elektrik çarpması ifadesiyle acil servise getirildiği, sağ el üçüncü parmakta elektrik çarpması giriş deliği tespit edildiği (Şekil-1), diğer sistem muayene bulguları ve tetkiklerinde herhangi bir patoloji saptanmadığı, izleminde de herhangi bir sorun gelişmemesi üzerine aynı gün taburcu edildiğinin belirtilmiştir. Muayenemizde sağ el üçüncü parmaktaki lezyonun iyileşmiş olduğu görüldü ve olay sonrası gelişen herhangi bir tıbbi şikayetinin olmadığı öğrenildi. $\mathrm{Bu}$ bulgular eşliğinde, kılavuzda her ne kadar elektrik çarpması giriş lezyonu bulunması yaşamsal tehlike olarak belirtilmekte ise de, vücudu kat etmeyen, elektrik akımı teması sonucu termal yanık ile karakterize lezyon oluşumuna neden olan yaralanmanın basit tıbbi müdahale ile giderilebilecek nitelikte olduğu şeklinde olmuştur.

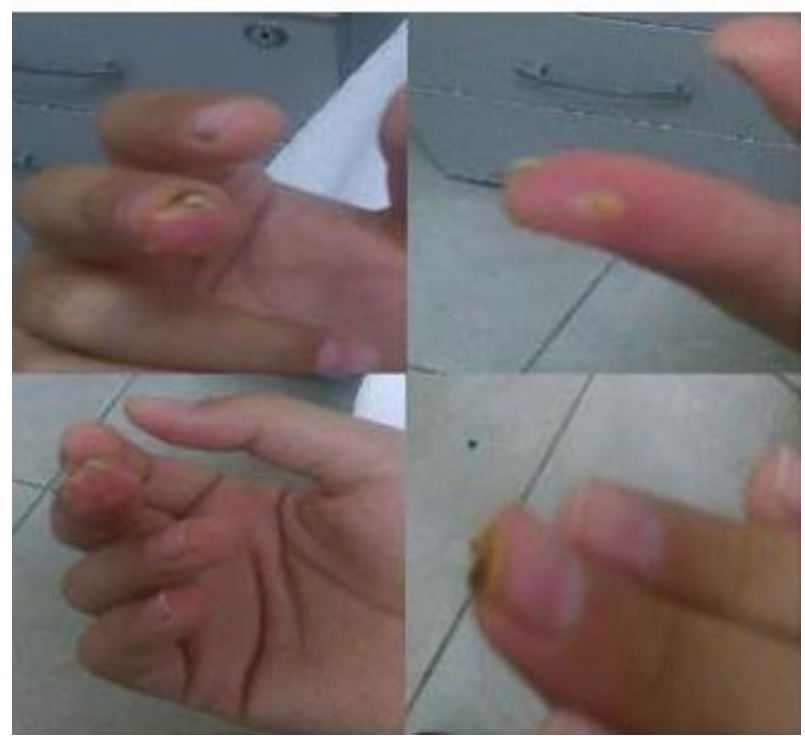

Şekil-1. Sağ el üçüncü parmak ucunda giriş lezyonu.

\section{Tartışma}

Elektrik çarpmalarında asıl hasar, akımın deriye giriş ve çıkış bölgelerinden ziyade, akımın oluşturduğu ısı etkisi sonucu vücutta izlediği yol üzerinde yer alan iç organlar ve kaslarda meydana gelen yanıklardır. Primer etki olarak termal hasar sonucunda deride koagulasyon nekrozu oluşmakta, ikincil etkiyle disritmi veya apne gibi hayatı tehdit eden komplikasyonlar meydana gelmekte, üçüncü olarak da sinir harabiyeti sonucu paralizi ve vazospazm oluşmakta, sinir gerilimine bağlı kas kontraksiyonları sonucunda ligament yırtıkları, kırıklar ve eklem çıkıkları meydana gelmektedir (3).

Elektriğin yaralanma veya ölüme neden olması için akımın bir noktadan diğer noktaya geçerken vücudu kat etmesi yani elektrik devresinin tamamlanması gerekir (1$4,9)$. Elektrik akımına en dirençli dokulardan biri olan deride maruz kalınan akımın yeterli amperde olması durumunda daima lezyon izlenir ve yuvarlak, oval veya uzunlamasına krater şeklinde, tabanı soluk veya koyu kahve renkli olan bu lezyona "elektrik yanığı" ya da "Joule yanığı" adı verilir $(1,9)$. Bununla birlikte banyoda, yüzme havuzunda veya ıslak zemin üzerinde görülen elektrik çarpmalarında, travma çok yüksek şiddette olsa bile, deride lezyon izlenmemektedir $(1,2,9)$. Bunun nedeni elektrik akımının geniş bir yüzeyden vücuda girmesi ve derinin ıslak olması nedeni ile direncin düşük olmasıdır (9).

İnsan vücudundan elektrik akımı geçmesi sonucunda ventriküler fibrilasyon, solunum ve kardiyak merkezlerin felci, solunum kasları spazmı ve termal yanıklar sonucu ölüm görülmektedir (1,3-5). Elektrik çarpması sonucu akut dönemde mortalite sıklıkla kardiyak nedenli 
olmaktadır $(1,3,4)$. Elektrik yaralanmaları kalbi iki yolla etkiler; birinci yol elektriğin direkt miyokardiyal nekroza neden olması, ikinci yol ise kardiyak aritmilere, sıklıkla da ventriküler fibrilasyona neden olmasıdır $(1,3,7,8)$. Elektrokardiyografide herhangi bir bulgu olmayacağı gibi sinüs taşikardisi, nonspesifik ST-T değişiklikleri, kalp blokları, QT uzaması, supraventriküler-ventriküler aritmiler ve atriyal fibrilasyon gibi değişiklikler de görülebilmektedir (3). Elektrik yaralanmalarında, elektrik akımı boyunca derin dokularda da hasar oluştuğundan, Crush sendromuna benzer şekilde, CPK, CK-MB ve LDH gibi çeşitli laboratuvar belirteçleri yükselmekte ve bunlarla birlikte başvuru anındaki lökosit değerleri, yanık oranları, elektrik akımının türleri klinik gidiş için ipucu verebilmektedir (7).

Elektrik çarpmaları, basit bir yaralanmadan ciddi çoklu organ yaralanmasına kadar geniş yelpazede hayatı tehdit eden bir yaralanmadır (5). Adli-tıbbi uygulamalarda elektrik akımı maruziyeti sonucu herhangi bir muayene ve laboratuvar bulgusu tespit edilemeyen olgularda veya elektrik akımı maruziyeti sonucu giriş ve/veya çıkış lezyonu ile birlikte ya da lezyon olmasa dahi kardiyopulmoner resüsitasyon uygulanan, yapılan tetkiklerde anormallik saptanan, elektrik teması sonucu yanık gelişen olgular hakkında düzenlenecek raporlarda, travma sonrası saptanan bulgu ve tetkiklerin tıbbi belgelere eksiksiz kayıt edilmesi halinde sorun yaşanmamaktadır. Fakat elektrik akımı maruziyeti sonucu vücudunda giriş ve/veya çıkış lezyonu saptanan ve bunun dışında gerek akut dönem ve izlemindeki muayenelerinde, gerekse de tetkiklerinde patoloji saptanmayan olguların medikolegal değerlendirmesinde çeşitli zorluklar karşımıza çıkmaktadır.
Elektrik çarpması sonucu, vücudunda sadece giriş lezyonu meydana gelen ve yapılan muayenelerinde, izleminde, tetkiklerinde herhangi bir patoloji meydana gelmeyen olgumuzda, kılavuzdaki ölçütlere göre değerlendirme yaptığımızda yaralanmanın yaşamsal tehlikeye neden olduğu şeklinde rapor düzenlenecekti. Fakat sadece termal yanık ile karakterize giriş lezyonunun bulunmasını yaşamsal tehlike için yeterli görmeyerek, bunun dışında herhangi bir patoloji oluşturmayan elektrik çarpması sonucu meydana gelen yaralanmanın basit tıbbi müdahale ile giderilebileceği şeklinde kanaate vardık.

Elektrik çarpması sonucu meydana gelen yaralanmaların değerlendirmesinde; sadece giriş ve/veya çıkış lezyonlarının bulunmasının yaşamsal tehlike sonucu için yeterli olmadığını, başvuru anında ve takiplerde saptanan ST-T değişiklikleri, kalp blokları, supraventriküler-ventriküler aritmiler ve atriyal-ventriküler fibrilasyon gibi EKG değişiklikleri ile lökosit, CK, CK-MB, LDH, AST-ALT, üre, kreatinin gibi doku hasar takibinde kullanılan laboratuvar bulgularında anlamlı yüksekliğin mevcut olduğu ölçütlerin kılavuzda yaşamsal tehlike kriterleri arasında yer alması gerektiğini düşünmekteyiz.

Elektrik çarpmasına bağlı yaralanmalar, morbidite ve mortaliteye neden olması nedeniyle önemli bir halk sağlığı sorunudur. Özellikle olgumuzda olduğu gibi, çocukların yaşam alanlarında kontrolsüz elektrik kaynaklarının bulunması yaralanmalara sebep olabilmektedir. Buna yönelik koruyucu önlemlerin aileler ve ilgili kurumlar tarafından hassasiyetle yerine getirilmesi, ayrıca çocukların eğitimlerinde elektrik çarpması ve benzer kazalara karşı farkındalığın arttırılması gereklidir.

\section{Kaynaklar}

1. Aksoy ME. Elektrik akımlarının neden olduğu yaralanmalar. Adli Tıp Bülteni 1997; 2(1):25-34.

2. Cantürk N, Alkan HA, Cantürk G. Ankara'da 2002-2006 yılları arasında otopsisi yapılmış elektrik akımına bağlı̈lüm olgularının değerlendirilmesi. Adli Tıp Dergisi 2008;22(2):1-7.

3. Gümüş A. Elektrik çarpması vakalarının demografik verileri ve yoğun bakım bulgularının incelenmesi (Yayımlanmamış Tıpta Uzmanlık Tezi). Dicle Üniversitesi Tıp Fakültesi Anesteziyoloji Anabilim Dalı, Diyarbakır, 2014.

4. Korkmaz M. Diyarbakır'da 2007-2014 yılları arasında otopsisi yapılmış elektrik akımına bağlı ölüm olgularının değerlendirilmesi (Yayımlanmamış Tıpta Uzmanlık Tezi). Dicle Üniversitesi Tıp Fakültesi Adli Tıp Anabilim Dalı, Diyarbakır, 2015.

5. Al B, Aldemir M, Güloğlu C, Kara IH, Girgin S. Elektrik çarpması sonucu acil servise başvuran hastaların epidemiyolojik özellikleri. Ulus Travma Derg 2006;12(2):135-42.

6. Cander B, Dur A, Koyuncu F, Gül M, Girişgin S. Elektrik yaralanmalarının demografik özellikleri ve yatış süresi üzerine etkili faktörler. Akademik Acil Tıp Dergisi 2010;2(1):72-4.

7. Türk Ceza Kanunu, Madde 87, 89, 95 Kanun Numarası: 5237, Kabul Tarihi: 6.09.2004

8. Balcı Y, Güzel S, Çetin G. Yeni Türk Ceza Kanunu'nda tanımlanan yaralama suçlarııın adli tıp açısından değerlendirilmesi. In: Balcı Y (ed). Herkes İçin Adli Tıp Cep Kitabı. Eskişehir; Eskişehir Osmangazi Üniversitesi Yayınları; 2008:203-35.

9. Akyıldız EÜ. Elektrik akımı lezyonlarında histopatolojik bulgular. Türkiye Klinikleri J Foren Med 2007;4(1):68-73. 